\title{
The Contextual Analysis of Private University's Informatization
}

\author{
Cao Yanyan \\ Network Security and Data Department \\ Xijing University \\ Xian, China \\ e-mail: cyy647@126.com
}

\author{
Liu Jingchao \\ Students Development and Service Center \\ Xijing University \\ Xian, China \\ e-mail: 805444342@qq.com
}

\begin{abstract}
To observe the different perspectives and effects of participants, in order to help the leadership to define the key issues need to be resolved in the private university's information strategy. This paper analyzes the perspectives of staff, leaders, students, cooperative enterprises and the government, and explains why they have such a perspective, and criticized some of the deficiencies in the development of the organization. Further from the perspective of management, it expounds the influence of these different perspectives on the construction of school information. It is believed that the information construction of private colleges and universities need to combine their own advantages and disadvantages, to listen to different voices of different positions, to stand in the development of the point of view to establish a good strategic planning and top-design. Of course, private colleges and universities in the running level and history are uneven, their views are not consistent. Leaders should optimize the allocation of resources, pay attention to the needs of campus users, the use of cross-border integration of "Internet + Education" concept, improve the effectiveness of information technology teaching, so that the school's wisdom to become the common goal of all stakeholders.
\end{abstract}

Keywords-perspective; stakeholder; informatization; wisdom; strategy

\section{INTRODUCTION}

Wisdom campus is the ultimate purpose of university's informatization construction. Perspectives are a matter of debate, different perspectives show different purposes and are influenced by the context ${ }^{[1]}$. People holding different stances are differences in the focus of attention. Such as someone are optimistic but someone are pessimistic at the same issue. Otherwise, there are considerable differences in people's ideas and ways throughout the process of dealing with problems. All of this can be due to the different perspective. Perspectives show different purposes, stakeholders and orientations. The school leadership must know about the different opinions from those stakeholders, different perspectives in wisdom campus construction, which is the basis on which to lay down the developmental strategy of the Informatization construction ${ }^{[2]}$.

\section{DIFFERENT PERSPECTIVES ON WISDOM CAMPUS}

The constructions of wisdom campus include improving basic network environment, perfecting the management informatization, establishing all kinds of "one-stop" service systems and so on. In all these works, different perspectives come from different contexts and different stakeholders who have different purposes. In private colleges and universities, the stakeholders have different rights and responsibilities, so their concerns are also very different.

TABLE I. POWER AND INFLUENCE

\begin{tabular}{|c|c|c|c|}
\hline \multirow{2}{*}{ Stakeholder } & \multicolumn{3}{|c|}{ Power and Influence } \\
\hline & Power & Influence & Comments \\
\hline Staff & Medium & High & $\begin{array}{l}\text { design and construct } \\
\text { informatization project }\end{array}$ \\
\hline Students & Low & Medium & campus network users \\
\hline $\begin{array}{l}\text { cooperative } \\
\text { enterprise }\end{array}$ & Low & High & $\begin{array}{l}\text { execute informatization } \\
\text { project }\end{array}$ \\
\hline Government & High & High & $\begin{array}{l}\text { eadership informatization } \\
\text { construction; evaluate the } \\
\text { quality of educational } \\
\text { informatization, etc. }\end{array}$ \\
\hline
\end{tabular}

In a university, the information construction of the participants are mainly divided into four parts: employees, students, cooperative enterprises and government, their influence and power are very different. The government's policy makers and supervisors, so his rights and influence, the student is the biggest beneficiary of informatization construction, but they lack the power and influence.

Figure 1. Stakeholders analysis.

\section{A. Staff's Perspective}

The development of the school can't be separated from each outstanding faculty and its staff team. While the campus construction became smarter, everyone expect that they can get development and improvement in the organization.

- they will be able to reflect more personal values in work, and can spend more time and energy to engage in higher-value works. Such as, participating in the development of wisdom campus building programs, making the school management application needs combining with the information technology, developing more reasonable and more scientific programs and plans. 
- Look forward that school changing the project construction mode. For instance, in the construction of integrated weak current wiring project, school should let the professional system integration company to organize the implementation, instead of using their staff whose have other own work to do.

- Other more, the staff should let themselves to participate in more technology summit, realize the professional skills upgrading, get the encouragment and affirmation of the leadership, improve the wage income. In this way, they can get a higher position and development ${ }^{[3]}$.

- One organization's biggest flaw is having no employee training. The construction of the wisdom campus involves many new technologies, such as virtualization, cloud computing, and so on. Schools need to organize technical training and management training. It can help the school's construction team to define the directions and objectives. Most of the time, we find that technology is not a problem and the key lies on the management ${ }^{[4-5]}$.

\section{B. Leadership's Perspective}

Between leadership and employee perspective is often the opposite, in considering the problems of foothold, leadership and staff have very different. Employees usually stand in the perspective of the implementation of the problem, and the leadership of the management point of view to think about the problem. Employees always feel that they pay more than the harvest, and the leadership of the school to give you more than you pay, which is a contradiction.

- $\quad$ "Do you worry about it?" The director of Network Security and Data Department (NSDD) favorite said this sentence. He hopes the employees can always have more time and energy for work, each employee is energetic and responsible, and they have more innovation and passion, more project examination and approval, more funds in place for a short period of time. This may be all of the information construction of colleges and universities leadership's expectation.

- Main leaders of the school consider that school informatization construction funds investment is too big. When talking about the construction of wisdom campus, there is just one word in their minds: money. And sometimes it's not necessarily effective. Even thought they believe that the school team's technical strength is not strong enough to complete the work, and the team should not rely too much on outside enterprises ${ }^{[3]}$.

- The construction of wisdom campus is bound to change the traditional management mode. The power and responsibility must be defined in the process of construction, to prevent the monopoly of technology, to avoid information and data leakage ${ }^{[7]}$.

The additional premise is that following, to build a new management system, to formulate corresponding rules and regulations, to make any work have rules-based. Even though informatization is an important part of the school's strategic planning and development, and it occupy larger proportion, but it cannot be ignored that the school need to give priority with teaching, so the application of education management informatization will be the core of wisdom campus construction.

\section{Perspective of Students}

Students are the largest benefit groups in wisdom campus construction. The student is the lifeline of the school, once the lack of private college students, the school is not far away from death. The construction of the wisdom campus provides students with convenient, but also proposes new challenge to the students management work.

- They hope that the campus network can be cheaper charge and faster speed in living quarters, the campus wireless network coverage more widely and more area can be free to use the internet and so on. They always hope their school's network is better than others. These are the aspirations of all students.

- Apartment building entrance guard system will directly record the situation of students in and out. Classroom monitoring system will be real-time recording the situation of lectures in the classroom. The teaching building of electronic attendance system will directly record the attendance of students and so on. Whether these basic management modes can be accepted by students, it will directly affect the construction progress of the wisdom campus ${ }^{[8]}$.

- Instead of waiting in line, the campus card is recharged by transferring from ALIPAY or bank. With the rapid updates of information technology, students need a richer experience of application of wisdom campus.

- By learning online, students can easily study more courses that they are interested in, can preview or review the information. Teachers can use multimedia equipment in classroom teaching, which can help them organize effectively. They only need submit electronic homework, and even replace examination with a paper and so on.

\section{Perspective of Cooperative Enterprise}

The benefit is primary purpose in most of cooperation between school and enterprise. The companies hope that obtaining the subject of business projects as much as possible, signing business contract and gaining the project advance payment as soon as possible. At the same time, the companies expect minimum cost and maximum profit, in order to accumulating a lot of experience of the project for the company. Moreover, the companies hope that passing the acceptance as early as possible, and getting the project progress payment, thus wining a competitive advantage in the industry.

In addition, the companies often think that the aftersales and secondary development is uncontrolled task, even giving up quality retention money. Therefore, the several companies put forward that the cost is extra in the late second development, thus organizing accordingly work. Similarly, the cooperative enterprise certainly expects that establishing a long-term development 
relationship with the school, in order to achieve win-win situation.

\section{E. Perspective of the Government}

If the government does nothing will be spurned by the people, but if the government did anything, as estimated that we will not be happy. In the information construction, the government should play a role in what level, we may not be the same view.

- The country and Shaanxi Province promulgated the relevant rules and regulations, such as the Private Education Promotion Law, education informatization of Shaanxi Province ten years of development planning (2010-2020), standardization construction of education informatization index system, shaanxi university work guidance data fusion, network information security system construction opinion, etc.

- The government hopes that private colleges and universities can regulate the running of schools and run schools according to the standard of education informatization.

- The Government give public universities student training funds, even offer special information construction funds, however, private universities have nothing. Therefore, private universities need to find more funding channels.

- The government encourages schools to build information systems and platforms, to promote a part of the school as soon as possible on the main management information system, in particular, to improve teachers and students based on the database, in the province wide pilot project to promote the wisdom of the campus, and promote the construction of data centers at all levels.

\section{From THE MANAGEMENT TO SEE THE EFFECTS OF} THESE GOALS

By analyzing the different perspective from the participants in the above informatization construction, it seems that the purpose may have a lot of impact. In many aspect of informatization construction, including both public colleges and private university, there is a same recognition the school require effective management if they are to provide the best possible application experience for their students and staff. Under the environment of government-led, as the higher education gathers pace, more school will realize that their main assets are their employees and partners, and they are becoming competitive depends on the application of information technology increasingly.

\section{A. Develop Staff's Abilities}

Everyone is a member of an organization, it is necessary to develop each member, in order to achieve the development of the organization.

- As an important part of implementing the informatization construction, when the school designs the top-level framework of the informatization, it should make a plan which develop their staff's technology abilities, thus training and improving their execution and innovation.
- The team is mostly young people who have dreams and pursuits in the wisdom campus construction. If they spent a lot of energies on the construction of integrated wiring, they save millions of construction funds for the school in the moment, but it is bound to hit their enthusiasm, because they aren't network migrant workers.

- Letting them bear the integrated wiring construction just can be a process as long as the understanding. School should let them put more energy in the more important construction projects, which stimulate the learning spirit, and promote the key technical competence for reserving force in the wisdom campus.

- In private universities, the personnel loss is more serious than public colleges. If there is a better platform which can exercise and improve, it is believed that more young people not only willing work here but also willing devote their youth to the school.

- The training plan should include two parts, one part is the cultivation of vocational technical ability; the other is the study of administrative management knowledge. Therefore, it is the key problem in the construction of wisdom campus, which is based on the combination of management and technology[3].

\section{B. Establish a Strategic Planning}

Strategic planning and strategic thinking relates to the future development of an individual or organization. It is not enough just to plan for the future, we must strategically plan for future. The planning process involves the confirmation of vision, mission, and values, which then leads to goals and targets for the future. Of course, it also needs to solve a few problems:

- Informatization construction is a process of high input and low output, and the investment is big but the short-term effect is not obvious, so the school needs to establish a long-term sustainable investment construction plan. The ultimate goal of the informatization construction must be applied, which should be balanced the relationship of construction and application. Heavy investment in light application will lead to a waste of funds, and it will lead to a loss of function in turn.

- Strategic planning requires a clear time node and project objectives. All aspects of coordination, once the project approval and implement, it can't be due to funding, personnel or other reasons to stop. And increase the project's initial research scope and expert demonstration period, so that every project can solve the problem of school management, and not to increase the burden of work.

- Gradually straighten out the relationship between builders, maintenance, users. In particular, to clarify the synergies between business and technology, so that technical support for project approval and supervision rather than business. Users should be the management and maintenance of the application of the information project, they 
need to participate in the construction process, in order to facilitate the late training and promotion.

In particular, leaders should give full trust and support to the team of wisdom campus construction, with the appropriate slowdown in the pace of construction, or more review and thinking. By effective timely communication and understanding each other, it reach the ratio of science resources, thus improve the construction of campus network based security system, and set up the top design of wisdom campus, in order to demand campus users with the perfect combination of information technology and so on.

\section{Focus on Application}

Wisdom campus construction provides convenient for the school's management, and changes traditional management mode. Only by the application of the technology is the most effective, only the application of students and staff recognition is convenient, only the input is recognized by the leadership is valuable.

- It is important that the school should pay attention to the feeling of the user groups of students. Don't let students think that the information technology hardware equipment or software system restrict their existence. Let the students feel the happiness and pride of life in a smart campus.

- Schools need appropriate to listen the heart-felt wishes of the user community, open up the collection channels of user demand, timely feedback the building concept and process, learn advanced typical construction experience, and emphasize on how to improve the application of informatization of education management, focus on how to apply information technology in teaching management ${ }^{[9-10]}$.

- Break the traditional concept, information is no longer a simple purchase of hardware and software, and absorb the new knowledge of "the industrial 4.0 " and “ Internet + ", and other new technologies, the school's information technology to combine with the teaching process, to achieve new heights of school personnel training strategy.

\section{Professional Partner}

Wisdom campus constructions always need professional information technology companies help it achieve the goal. Just like rock climbing, if there is an excellent partner, it will be able to protect your life. So choosing a good partner will directly affect the quality and progress of school construction. Because businessman always put the profit first, the school must consider many factors when choosing partners. For example, whether the company have the corresponding qualification and experience in similar project, how the social evaluate and so on.

Especially, school must pay great attention to the ability and ethic of the project manager and team who have been assigned. A company without similar experience will eventually be the school project as a test with small white mouse; finally, the biggest loser only is the school. When participating in school construction projects, the construction scheme is provided, the school management needs to adopt the principle of prudence, and the feasibility of the scheme is considered in detail.
After all, the company is standing on their own experience to put forward suggestions, only the school is the most understanding of their own situation. The cooperation with enterprises maybe not only at the business level, it is important that exploring the more ways of cooperation, and creating a win-win situation is the kingly way.

\section{E. The Government's Support}

In the aspects of information construction, the government only formulates guidance policy, and gives limited funds support, which is not conducive to long-term development of private universities.

The government should see its own unique institutional advantages, provide support for the development of private colleges and universities, rather than let private colleges and universities in the same platform, such as the development of private colleges and universities in the professional development and treatment policies, etc..

On the basis of the relevant policies, the university needs to establish the informationization strategy of toplevel design and implementation plan. The campus network use real-name authentication, in order to protect basic network security, and build a unified identity authentication, unified portal, data center platform gradually, thus realizing all kinds of one-stop service.

\section{CONCLUSIONS}

Perspectives on wisdom campus are an important premise about the informatizition construction strategic planning. This view comes from different stakeholders, such as students, staff, government and cooperative enterprise and so on. Through the analysis of different perspectives and their effects, we can clearly find that the importance of team cooperation, mutual communication and the establishment of consistent values, so that we can make the goal of wisdom campus becoming the majority stakeholder's common hope. Obviously, in such an environment of informatization construction, the goal should be to construction wisdom campus, focusing on improve the application of informatization of education management, focusing on training and improvement of the team, focusing on staff's ability of vocational technical and management, focusing on establish a long-term sustainable investment construction, advanced technology companies to help achieve the goal. In order to reach the common goal of the school campus wisdom, requires participants to cross-border integration each other, mutual understanding reached consensus on the idea, to realize the goal of school construction.

\section{REFERENCES}

[1] GILERS D L. Perspectives on leadership and management in education[M]. Australian: Flinders University, 2015.

[2] BRYSON J. Strategic planning for public and nonprofit organization : a guide to atrengthening and sustaining organizational achievement [M]. San Francisco: Jossey-Bass, 2011.

[3] The NSDD of Xijing University. The work summary[R]. China, Xijing University: the General Office of NSDD , 2014.

[4] BUSH T. Theories of educational leadership and management(4th ed.)[M]. London, England: SAGE, 2011.

[5] MEIGHAN R, SIRAJ-BLATCHFORD I. A sociology of educating(4th ed.)[M]. London, England: Continuum, 2003. 
[6] USEEM M, USEEM J, ASEL P, et al. Upward bound [M]. ZHOU Xue-lin, et al. Trans. Liaoning: Volumes Publishing Company.2004

[7] ZHAO Da-wei. The Internet thinking "lonely nine swords"[M]. Beijing: China Machine Press, 2014.

[8] SHEN Jian-yong. Under the background of "Internett" student rights protection[J]. Bejing: the Chinese Journal of ITC in Education, 2015, 10: 22-24.
[9] VIKTOR M S. Big data: a revolution that will transform how we live, work, and think[M]. SHENG Yang-yan, ZHOU Tao. Trans. Hangzhou: Zhejiang People's Publishing House, 2012.

[10] BILL F. Taming the big data tidal wave [M]. HUANG Hai, Trans. Beijing: Posts \& Telecom Press, 2013 